\title{
Neuroprotective Effect of Magnesium Sulfate and Dexamethasone on Intrauterine Ischemia in the Fetal Rat Brain: Ultrastructural Evaluation
}

\author{
Fetal Rat Beyninde Intrauterin Iskemide Magnezyum Sülfat ve \\ Deksametazonun Nöroprotektif Etkisi: Ultrastrüktürel Değerlendirme
} \author{
Erkan KAPTANOGLU ${ }^{2}$ \\ ${ }^{1}$ Oncology Training and Research Hospital, Department of Neurosurgery, Ankara, Turkey \\ ${ }^{2}$ Near East University, Faculty of Medicine, Department of Neurosurgery, Lefkosa, TRNC \\ ${ }^{3}$ Near East University, Faculty of Medicine, Department of Medical Biology, Lefkosa, TRNC \\ ${ }^{4}$ Hacettepe University, Faculty of Medicine, Department of Anatomy, Ankara, Turkey \\ ${ }^{5}$ Hacettepe University, Faculty of Medicine, Department of Biochemistry, Ankara, Turkey
}

Askin Esen HASTURK ${ }^{1}$, Ferhat HARMAN², Turkan ARCA³ ${ }^{3}$ Mustafa SARGON ${ }^{4}$, Kamer KILINC ${ }^{5}$,

Corresponding Author: Erkan KAPTANOĞLU / E-mail: erkankaptanoglu@gmail.com

\begin{abstract}
AIM: The aim of this study was to investigate the neuroprotective effect of magnesium sulfate and dexamethasone on oxidative damage in intrauterine ischemia.

MATERIAL and METHODS: In this study, 19-day pregnant rats were divided into five groups. Fetal brain ischemia was achieved in the ischemia/ reperfusion (I/R) group by bilaterally closing the utero-ovarian artery with aneurysm clips for $30 \mathrm{~min}$ and subsequently removing the aneurysm clips for $60 \mathrm{~min}$ for reperfusion. $\mathrm{Mg}(600 \mathrm{mg} / \mathrm{kg})$ and dexamethasone $(0.25 \mathrm{mg} / \mathrm{kg})$ were administered $20 \mathrm{~min}$ before the l/R insult. The lipid peroxidation in the brain tissue was determined by the concentration of thiobarbituric acid reactive substances (TBARS). The mitochondrial score was calculated after an evaluation with electron microscopy.

RESULTS: Both the electron microscope and TBARS data showed a significant difference between the control and I/R groups. The Mg and dexamethasone treatment groups exhibited significantly lower TBARS values compared to the IR group. Similarly, the mitochondrial scores in the $\mathrm{Mg}$ and dexamethasone treatment groups were significantly lower than those in the I/R group.
\end{abstract}

CONCLUSION: Result showed that magnesium sulfate and dexamethasone prevent lipid peroxidation and reduce mitochondrial injury thus suggests neuroprotective effects in fetal rat brain in intrauterine ischemia-reperfusion (I/R) injury.

KEYWORDS: Dexamethasone, Fetal brain, Injury, Intrauterine, Ischemia, Lipid peroxidation, Magnesium

Öz

AMAÇ: Bu çalışmada amaç, intrauterin iskemide oluşan oksidatif beyin hasarında magnezum sülfat ve deksametazonun nöroprotektif etkisinin araştırılmasıdır.

YÖNTEM ve GEREÇLER: Bu çalışmada 19 günlük gebe sıçanlar beş gruba ayrıldı. Fetal beyin iskemisi, utero-ovaryan arterin bilateral olarak 20 dakika anevrizma klipleri ile kapatılması ve kliplerin çıkarılmasında 60 dakika sonra reperfüzyon ile elde edilmiştir. İskemi-Reperfüzyon (I/R) hasarından 30 dakika önce intraperitoneal $600 \mathrm{mg} / \mathrm{kg}$ tek doz magnezyum sülfat ve $0.25 \mathrm{mg} / \mathrm{kg}$ dexametazon uygulanmıştır. Beyin dokusundaki lipid peroksidasyonu thiobarbituric acid reaktif madde (TBARS) konsantrasyonu olarak belirlenmiştir. Elektron mikroskopisi ile mitokondri incelemesi yapıldıktan sonra mitokondriyal skor hesaplandı.

BULGULAR: Hem electron mikroskobu ve hem de TBARS verileri kontrol ve iskemi grupları arasında anlamlı farklılık gösterdi. Mg ve deksametazon tedavi grupları iskemi gubuyla karşılaştırıldığında anlamlı derecede daha düşük TBARS değerleri gösterdi. Benzer şekilde Mg ve deksametazon tedavi gruplarında mitokondriyal skorlar iskemi gruplarından anlamlı düzeyde daha düşüktü.

SONUÇ: Sonuçlar magnesyum sülfat ve deksametazonun lipid peroxidasyonunu önlediğini ve mitokondriyal hasarı azalttığını, böylece fetal rat beyninde intrauterin iskemi-reperfüzyon (IR) hasarında nöroprotektif etkisi olduğunu destekledi.

ANAHTAR SÖZCÜKLER: Deksametazon, Fetal beyin, Travma, İntrauterine, İskemi, Lipid peroksidasyonu, Magnezyum 


\section{INTRODUCTION}

Brain injury due to intrauterine ischemia is one of the main causes of perinatal death and neurological injury $(2,19$, 26). The reperfusion period that begins following ischemia is the most critical period when severe injury occurs. Treatments given before this period may be able to prevent or reduce hypoxic brain injury $(1,9,24)$. Many interrelated mechanisms, such as the excessive stimulation of excitatory amino acid receptors, accumulation of intracellular calcium, lipid peroxidation, and free radical production play a role in pathophysiology of hypoxic brain injury $(1,2,24)$. Animal studies have made important contributions toward explaining these mechanisms and identifying new treatment approaches $(2,9,26)$.

The neuroprotective effects of magnesium sulfate and dexamethasone in ischemic brain injury are still being investigated. Their neuroprotective effects are explained by increased regional blood flow in the brain tissue, the nonspecific antagonism of voltage-dependent calcium channels, the noncompetitive inhibition of glutamatedependent N-methyl-D-aspartate (NMDA) receptors, the inhibition of glutamate release, the reorganization of the ischemia-induced disruption of cellular metabolism, and the balancing of calcium levels in the mitochondria $(2,8,26)$. The aim of the present study was to investigate the neuroprotective effects of magnesium sulfate and dexamethasone in intrauterine ischemic brain injury by brain tissue lipid peroxidation levels and brain tissue ultrastructural findings.

\section{METHODS}

This study was approved by the Institutional Animal Care and Use Committee of the Ankara Training Hospital in Ankara. The experiments were performed on 19-day-old pregnant Sprague Dawley rats (animal laboratory of Ankara Training Hospital in Ankara). The rats were housed separately at room temperature with a $12 \mathrm{~h}$ dark-light cycle and were allowed free access to water and food. The rats were randomly divided into five groups, with six animals in each group. First group was the control group. Brain tissue was taken from the control group immediately after laparotomy (Group 1: Control). Brain tissue was taken from the sham group 90 min after laparotomy (Group 2: Sham). Fetal brain ischemia was achieved in the ischemia-reperfusion (I/R) group by bilaterally closing the utero-ovarian artery with aneurysm clips for $30 \mathrm{~min}$ and then removing the aneurysm clips for $60 \mathrm{~min}$ for reperfusion (Group 3: Ischemia-reperfusion). The magnesium sulfate treatment group received a single $600 \mathrm{mg} / \mathrm{kg}$ intraperitoneal dose of magnesium sulfate 20 min before the I/R injury (Group 4: magnesium sulfate). The dexamethasone treatment group received a $0.25 \mathrm{mg} / \mathrm{kg} I \mathrm{P}$ dose of dexamethasone 20 min before the I/R injury (Group 5: dexamethasone). Tissue samples were taken immediately after I/R injury in Groups 3,4,5.

The surgical procedure was performed under general anesthesia with $10-\mathrm{mg} / \mathrm{kg}$ intramuscular injection of xylazine
(Xylazine, Bayern, Istanbul, Turkey) and 60- $\mathrm{mg} / \mathrm{kg}$ injection of ketamine hydrochloride (Ketalar, Pfizer, Warner Lambert, Istanbul, Turkey). After adequate anesthesia, the pregnant rats were placed in a supine position for the laparotomy procedure. Fetal ischemia was induced by bilaterally closing the utero-ovarian artery with aneurysm clips for $30 \mathrm{~min}$. A surgical microscope was used to assure the complete blockage and restoration of blood flow in the utero-ovarian arteries. Reperfusion was achieved by removing the clips from the arteries and restoring circulation for $60 \mathrm{~min}$. Whole fetal rat brains were removed at the end of the reperfusion period for tissue sampling. A very small portion of the brain tissue $\left(\approx 1 \mathrm{~mm}^{3}\right)$ from left motor cortex was preserved in glutaraldehyde for the electron microscopic analysis. The rest of the whole brains were stored in liquid nitrogen $\left(-196^{\circ} \mathrm{C}\right)$ for lipid peroxidation.

\section{Determination of Lipid Peroxidation}

The frozen tissue samples were weighed and homogenized in 1:10 (w:v) potassium phosphate buffer (50 mM, pH 7.4) with a Dounce homogenizer. The TBARS were measured as an index of lipid peroxidation using the method of Uchiyama and Mihara (22), and calculated as nano moles per gram of wet tissue.

\section{Transmission Electron Microscopic Examination}

The tissue samples were fixed in 2.5\% glutaraldehyde for 6 hours, washed in phosphate buffer (pH 7.4), post-fixed in $1 \%$ osmium tetroxide in phosphate buffer ( $\mathrm{pH} 7.4)$ for 2 hours, and dehydrated in increasing concentrations of alcohol. Next, the tissue samples were washed with propylene oxide and embedded in epoxy-resin embedding media. Semi-thin sections measuring approximately $2 \mathrm{Gm}$ in thickness and ultra-thin sections of approximately $60 \mathrm{~nm}$ in thickness were cut with a glass knife on an LKB-Nova (LKB-Produkter $A B$, Bromma, Sweden) ultramicrotome. The semi-thin sections were stained with methylene blue and examined using a Nikon Optiphot (Nikon Corporation, Tokyo, Japan) light microscope. The tissue blocks were trimmed after this examination, and ultra-thin sections were cut using the same ultramicrotome and stained with uranyl acetate and lead citrate. Following staining, all of the ultra-thin sections were examined with a Jeol JEM 1200 EX (Jeol Ltd., Tokyo, Japan) transmission electron microscope. The electron micrographs were taken by the same electron microscope. An investigator blinded to the study protocol examined the tissues. We used a grading system to perform a quantitative evaluation. The system was based on the method similar to that used for evaluating spinal cord tissue $(10,11)$. The mitochondria scoring parameters were as follows; 0: normal mitochondrion, 1: mitochondrion with prominent crista, 2: mitochondrion with cloudy swelling, 3: amorphous material collection inside the mitochondrion.

\section{Statistical Analysis}

The data were analyzed using a non-parametric Kruskal-Wallis test. The Mann-Whitney $U$ test was used as a post-hoc analysis for the pairwise comparison of groups within any particular 
assay. The data were expressed as the mean value \pm SE. A $p$-value $<0.05$ was considered to be statistically significant.

\section{RESULTS}

\section{Lipid Peroxidation}

There were no significant differences between the control and sham groups. TBARS data exhibited a significant difference between the control and I/R groups ( $p<0.001$ each), suggesting that the intrauterine $\mathrm{I} / \mathrm{R}$ model generated significant rise in lipid peroxidation in the intrauterine brain injury. Both magnesium sulphate and dexamethasone treatment groups showed significantly lower TBARS values compared to the I/R group ( $p<0.01$ and $p<0.001$, respectively). There was no difference between the TBARS results for the magnesium sulphate or dexamethasone treatment groups and the control groups. This finding suggests that pre-treatment with either magnesium sulphate or dexamethasone was sufficient to fully prevent to increase in lipid peroxidation in the brain tissue after I/R injury (Figure 1). When compared to each other magnesium sulphate and dexamethasone had no statistical difference in their effects on TBARS values or mitochondrial scores.

\section{EM Findings}

The transmission electron microscopic examination of the tissue samples from the control group revealed normal neuron, nucleus and mitochondria. There were no significant differences between the control and sham groups. Thus abdominal operation itself did not cause intrauterine ischemia. Statistical data revealed that there was significant difference between the control and I/R groups $(p<0.001$ each). Ischemia-reperfusion group revealed worse ultrastructural findings. Nearly all of the mitochondria in this group showed ultrastructural pathological changes and most of the mitochondria were swollen. Large vacuoles and intercellular edema were seen in the cytoplasm. No additional ultrastructural pathology was detected in nuclei, cell membranes or other organelles of the neurons. This result suggests that present intrauterine-I/R model generated significant mitochondrial damage and lipid peroxidation in the brain tissue exposed to I/R injury. Magnesium sulphate and dexamethasone treatment groups revealed less intercellular edema and better mitochondrial protection than ischemia-reperfusion group (Figure 2A-E). The mitochondrial scores in the magnesium sulphate or dexamethasonetreatment groups were significantly lower than those in the I/R injury group $(p<0.001)$. However, there was also a significant difference between the drug-treated and control groups $(p<0.001)$ (Figure 3$)$, suggesting that pre-treatment with either of these drugs could decrease the mitochondrial damage, but not to the pre-injury levels.

When compared to each other magnesium sulphate and dexamethasone had no statistical difference in their effects on mitochondrial scores.

\section{DISCUSSION}

Intrauterine ischemic brain injury and its associated complications are serious problems in both developed and developing countries. The lack of adequate effective treatments for the late period after intrauterine ischemic brain injury caused researchers to investigate treatments that are designed to prevent intrauterine ischemic brain injury and reduce the damage that occurs in the early period (1, $10,26)$. Although intrauterine ischemic brain injury causes complications, such as cerebral palsy, hearing and vision loss, attacks, and learning difficulties, it may be possible to treat it at the cellular level by reducing necrosis and apoptosis $(8,9,26)$. In the early period, necrotic cell death occurs as a result of hypoxia and ischemia (primary injury) $(1,10,11)$. After hours and days, neuronal death occurs during the late period, as a result of a complicated series of biochemical and molecular events that result in apoptosis (secondary injury) $(1,8,11,24)$. The chain of cellular events following ischemia and reperfusion period causes the excessive release of the excitatory amino acid glutamate, the stimulation of NMDA and other receptors, an increase in the calcium levels within

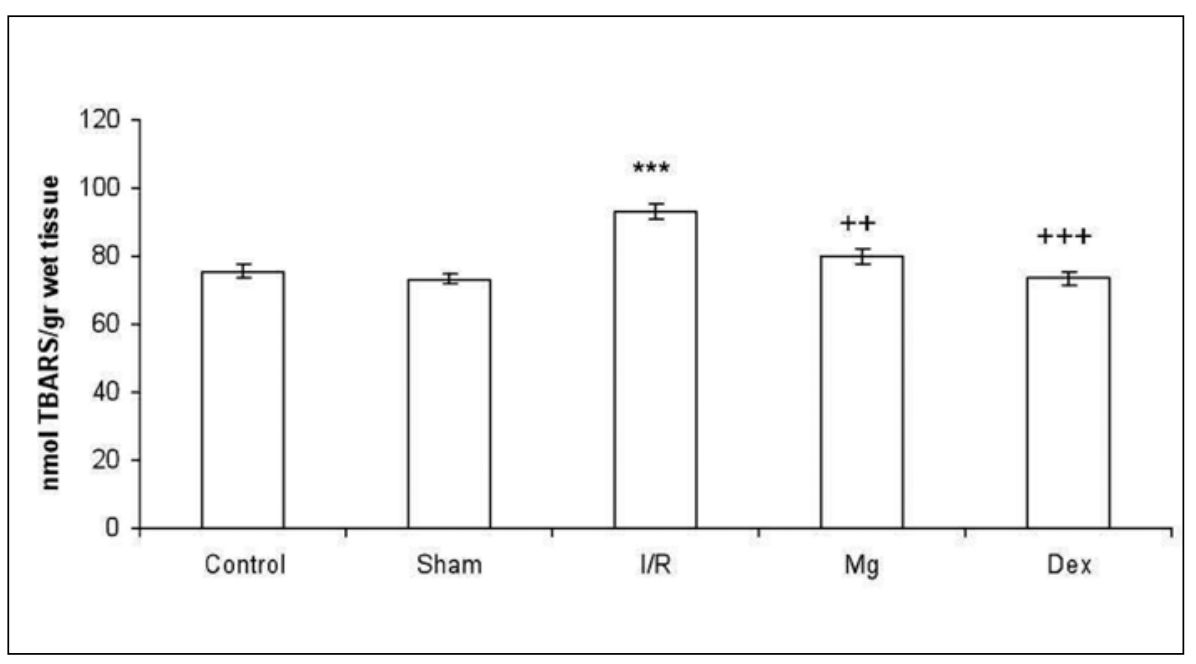

Figure 1: The levels of thiobarbituric acid reactive substances (TBARS) in fetal rat brain in control, sham, I/R and drug-treated groups. There is no significant difference in the levels between the control and sham groups. The lipid peroxidation products increased after ischemia-reperfusion $(\mathrm{I} / \mathrm{R})$ injury, but treating mothers with either magnesium sulfate $(\mathrm{Mg})$ or dexamethasone significantly decreased the TBARS values compared to the $I / R$ group. Asterisk represents comparison relative to the control and plus sign represents comparison relative to the I/R injury group (*** or +++ for $p<0.001$, ++ for $p<0.01$ ). 

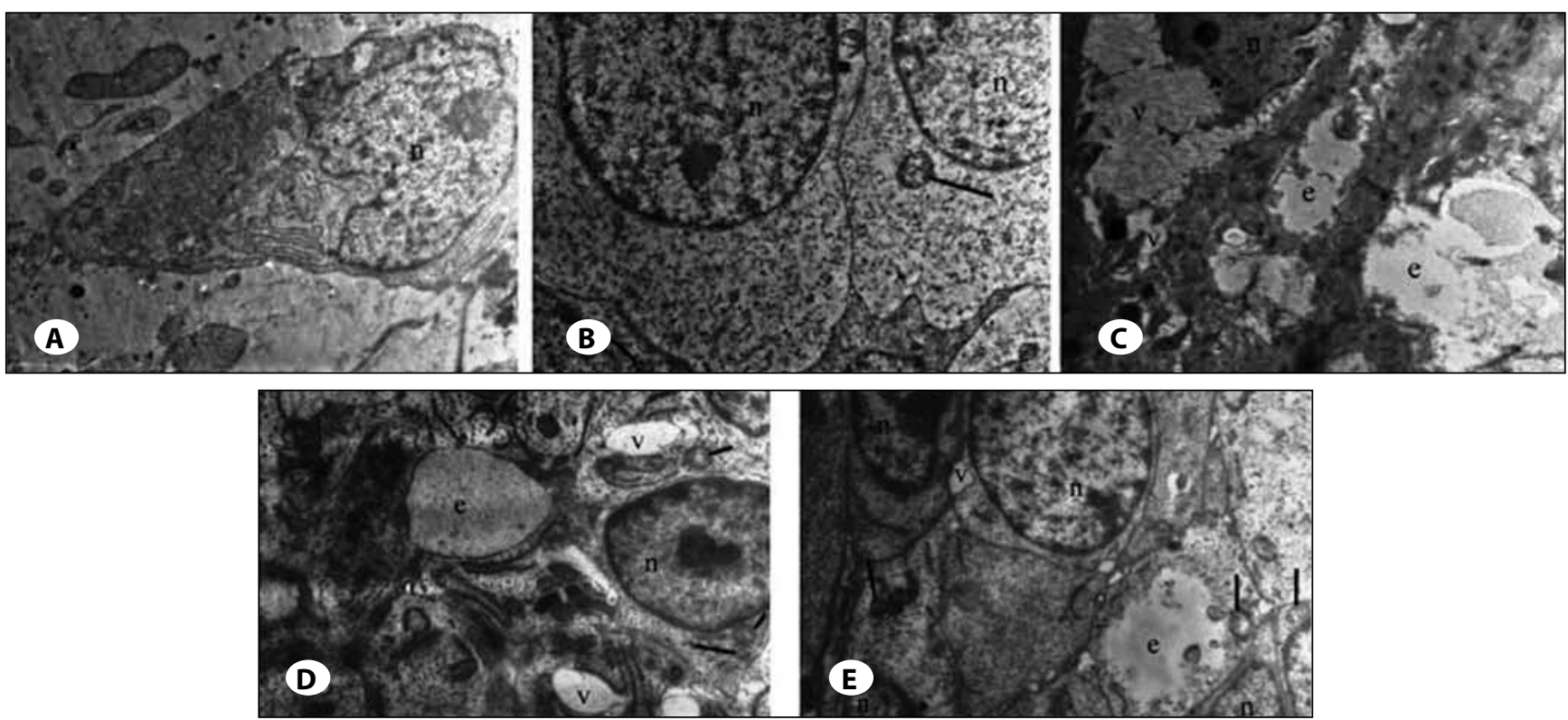

Figure 2: Electron microscopic evaluation. (A) A normal neuronal structure is observed in the control group. (B) Normal neurons and mitochondria are observed in the sham group (arrow). (C) Severe injury is observed in the ischemia-reperfusion (I/R) group. Intercellular edema is observed among the neurons and intracytoplasmic organelles attached to the large vacuoles. (D) Intercellular edema, intracytoplasmic vacuoles and mitochondria, and prominent crista are observed in the magnesium sulfate (Mg)-treatment group (arrows). (E) Intercellular edema, intracytoplasmic vacuoles and mitochondria, and prominent crista are seen in the dexamethasonetreatment group (arrows). Magnification: 6000X. Abbreviations: n: neuron nucleus, e: edema, v: vacuole.

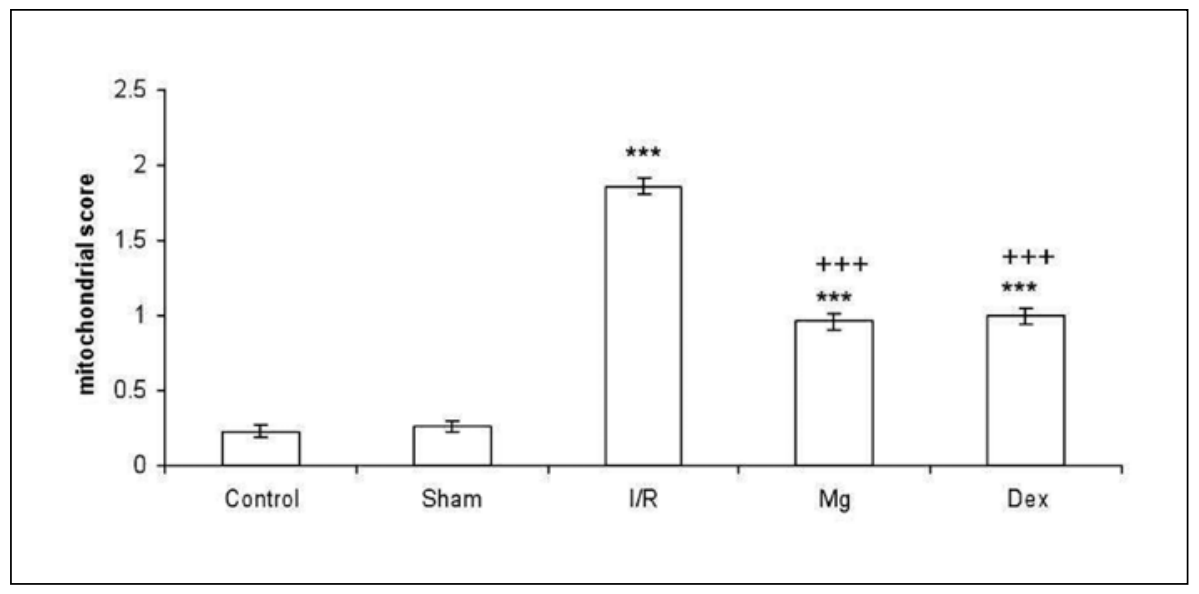

Figure 3: Mitochondrial scores of fetal rat brain in control, sham, I/R and drugtreated groups. The ultrastructural evaluation shows that mitochondrial damage occurred in the ischemiareperfusion (I/R) group, but treating mothers with either magnesium sulfate (Mg) or dexamethasone significantly decreased the mitochondrial score compared to that of the I/R group. Asterisk represents comparison relative to the control and plus sign represents comparison relative to the $I / R$ injury group (*** or +++ for $p<0.001$ ).

the cells, lipid peroxidation and the formation of arachidonic acid metabolites, the production of free oxygen radicals, and the activation of proteases, which result in irreversible cell death $(2,18,19)$. To date, various pharmacological agents and methods have been used to prevent injury in intrauterine ischemic brain injury models of the newborn $(2,9,24)$.

Magnesium sulphate is the main element in normal cellular functions, such as membrane integrity, cellular respiration, the establishment of normal sodium-potassium levels, and the regulation of calcium transport and accumulation (6, $7,18,21)$. It is used to limit secondary neuronal injury and ameliorate neurological consequences in some animal models of brain and spinal injury $(6,7,12)$. Magnesium sulphate was shown to have a direct effect on cellular metabolism during injury development after traumatic brain injury, in addition to playing a critical role in the regulation of other secondary injury factors $(7,12,21)$. Mg prevents $\mathrm{Ca}^{+2}$ entry into the cell by blocking NMDA receptors, thereby reducing intrauterine ischemic brain injury $(14,17,18)$. It has been shown that, magnesium sulphate treatment was a safe and effective method for preventing neurological complications in obstetrics patients $(6,17,18)$. Mg treated rats that were subjected to middle cerebral artery occlusion and reperfusion showed reduced brain infarction by accelerating electrophysiological and neurological healing (16, 17, 23). 
Researchers have shown that magnesium sulphate treatment reduced the delayed cerebral ischemia that occurred in patients with aneurysmal subarachnoid hemorrhage (SAH). A clinical study compared the effects of magnesium sulphate and nimodipine on the prevention of a delayed ischemic neurological deficit and determined that the utilization of magnesium reduced morbidity and hospitalization time $(14,16,23)$. We found that magnesium sulphate decreased both the TBARS values and mitochondrial scores when compared to ischemic brain injury group, however the effect of magnesium sulphate on mitochondrial scores was not as strong as its effect on TBARS. Our findings support that magnesium sulphate has neuroprotective effect by preventing lipid peroxidation and reducing mitochondrial damage and this is in accordance with the findings of other related studies $(7,17,18)$.

Dexamethasone is a synthetic corticosteroid that was used in brain edema and spinal cord injuries for a long time. Dexamethasone has demonstrated a beneficial inhibition of lipid peroxidation and neuroprotective effects $(4,5,15)$. The dexamethasone exerts a series of effects on injured neural tissue $(13,20)$. These effects are the regulation of energy metabolism, the prevention of progressive posttraumatic ischemia, the prevention of neurofilament degradation and the inhibition of membrane lipid hydrolysis $(3,4,25)$. Thus, it has been long believed that, with dexamethasone treatment, the structural and functional integrity of biological membranes can be preserved $(3,15)$. The primary mechanism of the neuroprotective effect of dexamethasone is the inhibition of lipid peroxidation $(4,5,15)$. In our work, dexamethasone decreased the TBARS values back to control levels and decreased the mitochondrial damage when compared to ischemic brain injury group. The neuroprotective effect of dexamethasone is well correlated with previous studies $(4,5$, $13,15)$. When compared to each other magnesium sulphate and dexamethasone had no statistical difference in their effects on TBARS values or mitochondrial scores suggesting that both drugs were equally neuroprotective in our study.

In summary, the neuroprotective effects of magnesium sulphate and dexamethasone on the central nervous system have been shown in previous experiments. In our work we evaluated the neuroprotective effects of magnesium sulphate and dexamethasone on fetal rat brain in an intrauterine ischemia-reperfusion model. According to our lipid peroxidation values and ultrastructural findings magnesium sulphate and dexamethasone may have a protective effect on intrauterine ischemic brain injury. The exact neuroprotective mechanisms of the treatments need to be elucidated in future studies.

\section{REFERENCES}

1. Berger R, Garnier Y: Pathophysiology of perinatal brain damage. Brain Res Rev 30: 107-134, 1999

2. Berger $R$, Garnier $Y$, Jensen A: Perinatal brain damage: Underlying mechanisms and neuroprotective strategies. J Soc Gynecol Investig 9: 319-328, 2002
3. Bruder ED, Lee PC, Raff H: Dexamethasone treatment in the newborn rat: Fatty acid profiling of lung, brain, and serum lipids. J Appl Physiol 98: 981-990, 2005

4. Flagel SB, Vázquez DM, Watson SJ Jr, Neal CR Jr: Effects of tapering neonatal dexamethasone on rat growth, neurodevelopment, and stress response. Am J Physiol Regul Integr Comp Physiol 282: 55-63, 2002

5. Flavin MP: Influence of dexamethasone on neurotoxicity caused by oxygen and glucose deprivation in vitro. Exp Neurol 139: 34-38, 1996

6. Hallak M, Hotra JW, Kupsky WJ: Magnesium sulfate protection of fetal rat brain from severe maternal hypoxia. Obstet Gynecol 96: 124-128, 2000

7. Heat DL, Vink R: Optimization of magnesium therapy after severe diffuse axonal brain injury in rats. J Pharmacol Exp Ther 288: 1311-1316, 2003

8. Johnston MV: Excitotoxicity in neonatal hypoxia. Ment Retard Dev Disabil Res Rev 7: 229-234, 2001

9. Johnston MV, Trescher WH, Ishida A, Nakajima W: Neurobiology of hypoxic-ischemic injury in the developing brain. Pediatr Res 49: 735-741, 2001

10. Kaptanoglu E, Palaoglu S, Surucu HS, Hayran M, Beskonakli E: Ultrastructural scoring of graded acute spinal cord injury in the rat. J Neurosurg 97: 49-56, 2002

11. Kaptanoglu E, Sen S, Beskonakli E, Surucu HS, Tuncel M, Kilinc $\mathrm{K}$, Taskin Y: Antioxidant actions and early ultrastructural findings of thiopental and propofol in experimental spinal cord injury. J Neurosurg Anesthesiol 14:114-122, 2002

12. Kaptanoglu E, Beskonakli E, Okutan O, Surucu HS, Taskin Y: Effect of magnesium sulphate in experimental spinal cord injury: Evaluation with ultrastructural findings and early clinical results. J Clin Neurosci 10: 329-334, 2003

13. Kauffman F, Seidler FJ, Slotkin TA: Prenatal dexamethasone exposure causes loss of neonatal hypoxia tolerance: Cellular mechanisms. Pediatr Res 35: 515-522, 1994

14. Muir KW, Lees KR, Ford I, Davis S; Intravenous Magnesium Efficacy in Stroke (IMAGES) Study Investigators: Magnesium for acute stroke (Intravenous Magnesium Efficacy in Stroke Trial): Randomised controlled trial. Lancet 363: 439-445, 2004

15. Neal CR Jr, Weidemann G, Kabbaj M, Vázquez DM: Effect of neonatal dexamethasone exposure on growth and neurological development in the adult rat. Am J Physiol Regul Integr Comp Physiol 287: 375-385, 2004

16. Prevedello DM, Cordeiro JG, de Morais AL, Saucedo NS Jr, Chen IB, Araujo JC: Magnesium sulfate: Role as possible attenuating factor in vasospasm morbidity. Surg Neurol 65: 14-20, 2006

17. Pyne GJ, Cadoux-Hudson TA, Clark JF: Magnesium protection against in vitro cerebral vasospasm after subarachnoid hemorrhage. Br J Neurosurg 15: 409-415, 2001

18. Solaroglu A, Suat Dede F, Gelisen O, Secilmis O, Dede H: Neuroprotective effect of magnesium sulfate treatment on fetal brain in experimental intrauterine ischemia reperfusion injury. J Matern Fetal Neonatal Med 24: 1259-1261, 2011 
19. Solaroglu I, Okutan O, Solaroglu A, Kaptanoglu E, Beskonakli E, Kilinc K: Maternal treatment with propofol attenuates lipid peroxidation after transient intrauterine ischemia in the neonatal rat brain. Biol Neonate 85: 221-224, 2004

20. Tuor UI, Chuman PD, Del Bigio MR: Prevention of hypoxicischaemic damage with dexamethasone is dependent on age and not influenced by fasting. Exp Neurol 132: 116-122, 1995

21. Turkyilmaz C, Turkyilmaz Z, Atalay Y, Soylemezoglu F, Celasun $B$ : Magnesium pretreatment reduces neuronal apoptosis in newborn rats in hypoxia-ischemia. Brain Res 955: 133-137, 2002
22. Uchiyama M, Mihara S: Determination of malonaldehyde precursors in tissues by thiobarbituric acid test. Anal Biochem 86: 271-278, 1978

23. van den Bergh WM, Algra A, van Kooten F; MASH Study Group: Magnesium sulfate in aneurismal subarachnoid hemorrhage: A randomized controlled trial. Stroke 36: 1011-1015, 2005

24. Vannucci RC: Hypoxic-ischemic encephalopathy. Am J Perinatol 17: 113-120, 2000

25. Whitelaw A, Thoresen M: Antenatal steroids and the developing brain. Arch Dis Child Fetal Neonatal Ed 83: 154-157, 2000

26. Yager JY: Animal models of hypoxic-ischemic brain damage in the newborn. Semin Pediatr Neurol 11:31-46, 2004 